\title{
Uma análise das tensões ideológicas através da palavra e do discurso trovadoresco (Portugal - século XIII)
}

\section{José D’ AssunçÃo BARRos}

\author{
Doutor em História pela Universidade Federal \\ Fluminense, professor da Universidade Severino \\ Sombra, Vassouras - RJ.
}

Resumo: Discussāo acerca das forças ideológicas que atravessam a sociedade e a cultura medieval ibérica, com o exame particular do jogo de suas tensões políticas e sociais, através da prática literária dos trovadores e da própria significação da palavra "trovador", expressão que, capaz de apresentar-se como uma acirrada arena de conflitos sociais, realça, por fim, tal jogo de tensōes em algumas cantigas desse período.

Palavras-chave:trovadores medievais; poesia satírica; literatura medieval; tensōes sociais; discurso político
Abstract: This article aims to discuss the ideological tensions present in medieval Iberian society and culture, examining in particular the interplay in its political and social tensions, manifested in the troubadours' literary practice. It opens with a discussion of the term "troubadour", an expression which presents, in itself, a rich arena of social conflict, and stresses some playful tensions in some songs of the time.

Keywords:medieval troubadours; satiric poetry; medieval literature; social tensions; political discourse 
Se a ideologia atravessa necessariamente o discurso e as práticas discursivas, em todos os gêneros literários, tal não poderia ser diferente com a poesia trovadoresca medieval. O objeto do presente artigo, nesta mesma direção, refere-se às relações entre Ideologia e Discurso através das práticas trovadorescas. Pretendese dar a perceber como a Ideologia constitui, atravessa, recorta este discurso - e como se instala no discurso trovadoresco, não apenas através da poesia mas também da própria possibilidade de nomear e classificar os seus praticantes, dentro de determinada hierarquização social e de uma 'luta de representações' que se desenvolve em torno dessa maneira de hierarquizar. A palavra torna-se arena para lutas ideológicas, e a própria palavra "trovador" torna-se um espaço que se expande ou se comprime conforme as diversificadas intervenções sociais, conforme ficará demonstrado mais adiante.

Consideraremos inicialmente que, em um mundo cultural ainda regido essencialmente pela oralidade, penetramos com o discurso trovadoresco medieval em uma modalidade literária para a qual confluem a poesia, a música, o espetáculo, a gestualidade. De igual maneira, também se mostram como espaços de imbricamento de várias linguagens os cancioneiros do período - registros dessa vasta produção que circulava oralmente nos saraus senhoriais e palacianos, na universidade, na praça pública e em tantos outros ambientes socioculturais. Para além do registro em que se coloca por escrito uma poesia veiculada oralmente e através da música - e que muitas vezes inclui tanto a escritura do verso como uma partitura musical - os cancioneiros abrem-se para a visualidade através de iluminuras que buscam expressar em manuscrito a dimensão de espetáculo em que se pautava toda atividade trovadoresca. Temos aqui, portanto, um discurso complexo e múltiplo: oral, escrito, musicado, visual, gestualizado - e todas as dimensões desse complexo discurso vêem-se constituídas e atravessadas pelo ideológico. 
Existe também outra dimensão fundamental que pode ser percebida na poesia trovadoresca da Idade Média. Tratase de um discurso que é ponto de encontro, ou ponto de tensão, entre o individual e o coletivo. Puro espaço de poder, através dessa poesia também a Sociedade, no seu sentido mais amplo, encontrava um excelente caminho para as suas representações sociais. O mundo dos trovadores, conforme veremos, é um mundo de tipos sociais diversos, de tensões sociais e políticas, de extratos culturais que se entrechocam, de projetos políticos que se enfrentam, de micropoderes que fazem da poesia dos trovadores uma verdadeira "arena trovadoresca". Tal se verifica com especial ênfase na poesia satírica, onde as tensões diversas encontram livre espaço para manifestar-se através da sátira e do riso. O nosso objetivo a seguir, portanto, será o de verificar como a própria linguagem, através do gênero poético, configura-se no mundo trovadoresco em espaço de disputas e de enfrentamentos onde se estabelecem verdadeiras guerras de representações. A ênfase do estudo recairá no trovadorismo ibérico, comumente chamado de trovadorismo galego-português em função deste que era o idioma poético utilizado tanto pelos trovadores de Portugal como pelos de Leão e Castela. Iniciaremos com uma investigação da arena de tensões sociais que se estabelece no próprio interior da palavra "trovador".

Recuemos, para uma melhor compreensão do problema, às origens vagas e imprecisas desse fenômeno trovadoresco medieval tornado tão expressivo a partir do século XI. Desde os primórdios da Idade Média se tem notícia, aqui e ali, de poetas-cantores que percorriam o lado ocidental europeu atuando como músicos, cantores, recitadores e que, por vezes, se ligavam a outras formas de espetáculo. Menestréis, jograis, trovadores — são tão diversas quanto imprecisas as designações que surgiram para dar conta desse enorme conjunto de poetas-cantores que esconde, na verdade, uma grande gama de possibilidades e tipos. Skops anglo-saxônicos desde o século IV, escaldos islandeses e noruegueses a partir do século $\mathrm{X}$, trovadores cortesãos do século XII em diante, goliardos desde o século IX, jograis um pouco por toda a Idade Média — nem sempre é fácil identificar 
as nuanças entre esses vários tipos. A designação "jogral", por exemplo, é uma das mais vagas - já que, por vezes, se refere não apenas ao músico-poeta, mas também ao artista saltimbanco, ao histrião, ao malabarista e a tantos outros profissionais do espetáculo.

Existem certas características comuns que tocam - todo o grande conjunto de poetas-cantores medievais, como a "itinerância" de boa parte de seus participantes ou a oralidade de sua produção. A entender por esses critérios, a cultura medieval contou com uma longa duração de movimentos trovadorescos nas várias partes da Europa. E, contudo, nessa espécie de "longa duração trovadoresca" se inscrevem durações mais curtas - compreensíveis a partir de uma história estrutural e lenta que permite isolar os diversos trovadorismos de acordo com as sociedades que os envolvem. Para dentro deles, uma vez ainda, o tempo curto e dramático dos acontecimentos parece agitar aquelas poéticas singulares, fornecendo temas e paixões para os seus poetas-cantores: uma batalha, uma mulher, uma traição, o destronamento de um rei - mas também uma hierarquização social que se defende ou contra a qual se resiste, uma visão de mundo que aflora, um discurso social que mais uma vez se enuncia. Tudo é matéria-prima para um verso.

De qualquer forma, deve-se levar em conta que o movimento trovadoresco - enquanto designação - pode ser entendido tanto naquela acepção mais ampla como na mais restrita. Em sua acepção mais ampla, ele indica aquele grande circuito de produção e circulação poética e musical que atingia diversas esferas, desde a palaciana e cortesã até a popular, desde o ambiente rural até o urbano, desde as festas até as cruzadas, e que, por fim, se enquadra em uma duração que se confunde com o próprio período medieval. $\mathrm{Na}$ acepção mais restrita, o movimento trovadoresco remete ao âmbito das cortes régias e senhoriais a partir do século XI, quando a cultura aristocrática assimila a produção poéticomusical como uma de suas atividades distintivas.

Assim, essa acepção mais restrita representa uma espécie de recorte, no espaço social e no tempo, dentro da produção trovadoresca mais ampla. Refere-se, pois, à 
poesia, popular ou aristocrática, que circulava no meio cortesão — notando-se que dessa circulação participavam os mais diversos tipos sociais. Além disso, remete a um período que vai do século XI ao XIV, estendendo-se ao século XV em algumas cortes alemãs. Característica comum a boa parte dos trovadores medievais de que trataremos aqui era, tal como se disse, a sua itinerância, ainda que esta não deva ser exagerada, já que muitos trovadores se estabeleciam a seu tempo em alguma corte ou região. Ser um meio movente traz uma efervescência especial ao meio trovadoresco. O trovador liga-se por essa afinidade àquelas figuras do cavaleiro andante, do clérigo errante, do mercador e navegante, cada qual como um elemento importante no processo de transformação da sociedade medieval a partir do século XI. Ao mesmo tempo, a itinerância punha em contato todos os trovadores, facilitava as trocas culturais e criava uma grande malha que recobria todo o Ocidente europeu com seu tecido de versos e sonoridades.

O grande concerto dos poetas-cantores tinha, contudo, seus timbres internos. Para efeito de simplificação, consideremos as cinco principais regiões culturais que cobrem a produção trovadoresca:

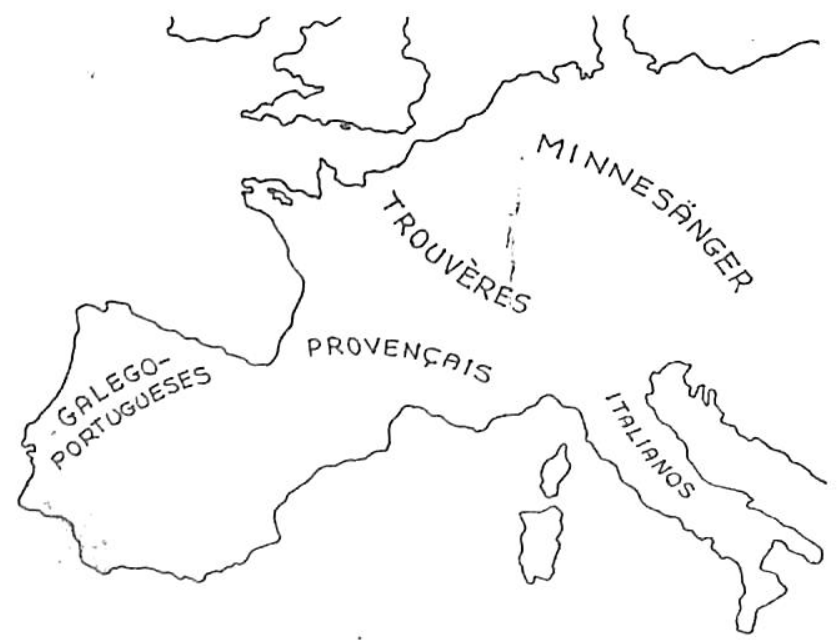

Figura 1 - Mapa trovadoresco do Ocidente medieval entre os séculos XI e XIV 
A França se via então dividida culturalmente em norte e sul, gerando daí dois subconjuntos distintos e separados pela linguagem. No sul occitânico, o subconjunto "provençal" dos troubadours, da langue d'oce da civilização cátara, berço do amor cortês. No norte, os trouvères, cantando na langue d'oil as primeiras canções de gesta. Em torno do vale do Pó, foi mais tardio o movimento dos "trovadores italianos", dando origem ao chamado dolce stil nuovo. Na Alemanha, a Minnesang contribuía com sua versão germânica para o amor cortês (minne = amor sutil) e para outros gêneros trovadorescos. Finalmente, o subconjunto dos trovadores galego-portugueses, que unificava através de uma língua poética comum boa parte da Península Ibérica cristã (com exceção de Aragão e da Catalunha, mais ligados ao circuito provençal).

Dos cinco subconjuntos destacados, o Provençal pode ser tomado como o grande pólo de irradiação que detonou o trovadorismo de corte. A grande novidade trazida por estes troubadours do sul occitânico (cortes da Provença, Toulouse, região da Catalunha) foi sem sombra de dúvida o Amor Cortês. Explica a sua irresistível difusão por toda a Europa Feudal o fato de que esse novo modelo do sentir estava em imediata sintonia com os valores feudo-vassálicos do seu tempo, com formas apaixonadas de religiosidade que então surgiam, com necessidades sociais interfamiliares que proporcionaram o surgimento não apenas dos trovadores, mas também dos cavaleiros andantes em busca de aventuras e de oportunidades.

Em que pese ao papel pioneiro e difusor representado pelo circuito provençal para os demais pólos do trovadorismo europeu, outro circuito poético que deixou uma contribuição intensamente original foi o dos trovadores galegoportugueses. Estes, sobretudo na sua produção satírica e na forma como foram incentivados pelos reis centralizadores de Portugal e de Castela, abriram espaço nas suas cortes trovadorescas para a expressão de poetas-cantores advindos das mais diversas procedências e categorias sociais. O duelo lírico, mais neste ambiente trovadoresco ibérico do que em outros, era incentivado pelo rei e por seus convivas, tornando- 
se favorável a que hoje se tenha um verdadeiro retrato das tensões sociais da época com base no exame das páginas do cancioneiro galego-português, onde os trovadores de vários níveis sociais se enfrentavam e se satirizavam uns aos outros.

Consideremos, a partir daqui, a diversidade social que nos apresenta esse ambiente trovadoresco mais restrito das cortes régias e senhoriais. $O$ poeta-cantor podia ser tanto um trovador nobre (trovador-fidalgo) como um jogral de menor categoria social. Havia por vezes uma tendência do trovador nobre em reivindicar para si mesmo a designação trovador, como uma espécie de distinção social, enquanto reservava a designação jogral àqueles poetas-cantores que não eram de origem nobre. Acompanhava essa disposição uma pretensão, apenas teórica, de que os cavaleiros nobres é que deviam atuar como compositores, enquanto os jograis deveriam ser relegados ao papel de meros cantores e acompanhadores. Naturalmente que tal pretensão, cantada e decantada por alguns nobres, permanecia estéril na prática, já que alguns dos melhores poetas-compositores pertenciam a extratos sociais diversificados, do burguês enriquecido ou remediado ao jogral que dependia da atividade artística para o seu sustento.

Este ponto também permeia a reivindicação do título de trovador pelos nobres, que se colocavam como diletantes que em tese não dependiam do "trovar" para o seu próprio sustento material. Trovar era para alguns dos nobres um distintivo social e um instrumento de prestígio, e não um meio de subsistência. Nesta esteira depreciavam socialmente os jograis, para quem o trovar estava associado a uma forma de ganhar a vida. Muitos destes tinham os seus serviços contratados pelos trovadores nobres, fosse para acompanhálos como instrumentistas e cantores, fosse para difundir suas composições. Emerge daí uma terceira designação, comum em alguns subconjuntos como o galego-português. Enquanto o jogral propriamente dito estava atrelado aos serviços de outro, fosse ele um nobre ou um trovador não-nobre que o contratava, o segrel seria um jogral, ou um trovador nãonobre que adquirira certa independência e, em alguns casos, até podia se dar ao luxo de contratar os serviços de outrem. 
É claro que tal circuito de designações era difundido por alguns nobres interessados em firmar sua posição de classe, não correspondendo a uma aceitação por parte dos segréis e jograis que se viam excluídos e que reivindicavam para si mesmos, como compositores, a designação de trovadores.

Essa pluralidade de designações (polinomásia) atribuídas ao mesmo agente - o poeta-cantor atuante nas cortes trovadorescas - bem como a disputa entre os vários tipos sociais pelo monopólio de uma designação ou, no caso dos jograis, pelo simples direito de partilhá-la, é o principal vestígio de uma intensa luta pelo poder de nomear que se travava no seio do universo cortês ${ }^{1}$. A polêmica sobre quem deve ou não ser classificado como trovador aparece estampada em algumas cantigas satíricas do Cancioneiro Galego-Português, às quais recorreremos no momento apropriado. É mais temática aí do que em outros subconjuntos trovadorescos, simplesmente porque entre os galego-portugueses as cantigas satíricas adquirem um maior teor de crítica de tipos sociais e de sátira pessoal.

Por esse viés, percebe-se que a palavra "trovador" é outra daquelas que comportam múltipla acepção. "Como indicávamos no começo, as palavras mudam de sentido segundo as posições assumidas por aqueles que as empregam; pode-se precisar agora: as palavras 'mudam de sentido' ao passar de uma formação discursiva para outra" (HAROCHE, HENRY e PÊCHEUX, 1971, p.115). Ora, a "formação ideológica trovadoresca" abre-se (não sem luta) para múltiplas "formações discursivas", e a primeira que aqui examinamos é precisamente esta que se orienta da nobreza mais tradicional e demarcadora contra os grupos sociais nãoaristocratas que se imiscuem na arena trovadoresca e lutam pelo direito de ver-se representados.

Nesse "sentido mais restrito" invocado por esses nobres preocupados em demarcar uma posição de classe, a palavra "trovador" atém-se, portanto, aos músicos-poetas a um só tempo aristocratas e independentes. Tal acepção se constrói por oposição ou contraste com as denominações "segrel" e "jogral". A mentalidade feudal é que está por trás dessa intenção de classificar e hierarquizar a pluralidade
${ }^{1}$ Leo Spitzer introduziu essa perspectiva em seu estudo sobre Dom Quixote ("Perspectivism in Don Quixote" em Linguistics and literary history, New York: Russel and Russel, 1948), onde mostra que "a polinomásia, quer dizer, a pluralidade de nomes, sobrenomes, alcunhas que são atribuídos ao mesmo agente ou à mesma instituição é, com a polissemia das palavras ou das expressões que designam os valores fundamentais dos grupos, o vestígio visivel das lutas pelo poder que se travam no seio de todos os universos sociais". Resumo de Pierre Bourdieu, em O poder simbólico (1989, p.146). 
trovadoresca a partir da perspectiva da nobreza mais tradicional e de critérios de qualidade de dependência pessoal. Acompanha um desprezo, entranhado no imaginário cavaleiresco, por aqueles que são dependentes unilaterais de um patrão - o jogral — ou por aqueles que "trovam" para ganhar a vida, no que se enquadram alguns segréis mas também muitos nobres empobrecidos. Estes também se tornam vítimas, neste último caso, da exclusão. Mas, sem perder a noblessee o orgulho, empurram por sua vez a linha demarcatória para além de si. Invocam para a palavra "trovador" um vínculo com a origem social aristocrata, e não com a situação de diletância.

Como se sabe, ao contrário do que ocorre em algumas outras áreas da Europa, o feudalismo ibérico é perturbado pela emergência de um tipo especial de cavaleiro de origem vilã, isto é, não-aristocrata. Associado por vezes a atividades produtivas e mercantis em franca ascensão, e sem os entraves imaginários que encerram a nobreza dentro de um repertório feudo-vassálico de alternativas para o seu sustento, o cavaleiro vilão é muitas vezes mais resolvido economicamente que diversos nobres. Isso solapa as bases daquela intenção, proveniente da parte mais tradicional da aristocracia, de demarcar os limites da palavra "trovador" a partir da diletância, tornando-se este um argumento a favor dos próprios cavaleiros vilãos economicamente bem resolvidos. Particularmente nos meios trovadorescos ibéricos, estes reivindicam, logo para si, a denominação de "trovador". Empurram a linha demarcatória para mais adiante e depreciam somente aqueles jograis economicamente dependentes da profissão de músicos-poetas - sejam segréis autônomos mas miseráveis, ou jograis "assoldadados" por outros trovadores. Gera-se, dessa forma, uma nova "formação discursiva", com novos critérios de demarcação os quais são tenazmente defendidos pelos seus enunciadores.

Mas, por fim, os jograis que se tornaram "compositores" - e não apenas meros cantores e instrumentistas - empurram mais uma vez a linha fronteiriça dessa palavra tão múltipla e flexível. Para eles, o que categoriza o "trovador" é o seu status de criador, de buscador de 
palavras, o que, aliás, está na origem etimológica do termo (trouver $=$ encontrar). Nesse caso, o próprio jogralcompositor cria uma distinção entre seu tipo e o do jogral "mero acompanhante" ou "cantador das cantigas de outros". Essa "formação discursiva" deve vir carregada, evidentemente, de argumentos de natureza inteiramente diversa daqueles de índole "hierárquica" ou "econômica". Defende-se aqui uma definição "estética" ou "artística" para a palavra.

A palavra "trovador" é algo como uma armadura que todos querem vestir, e que alguns pretendem interditar. Por um lado, é o único espaço onde o peão mais miserável pode pretender, através da arte, se igualar ao fidalgo de alta estirpe. "O talento é que é a verdadeira nobreza, não o nascimento", parece nos dizer o jogral em suas harmonias ocultas. Mas, por outro lado, quando é manejada de outra forma, a palavra "trovador" se torna mais um instrumento de demarcação social, no momento mesmo em que o trovador-fidalgo pretende interditá-la ao jogral. Armadura elástica, a palavra se expande e se contrai conforme interesses vários e as intenções sociais que a animam. Até esse ponto, parece possível inferir aquela sugestão de Mikhail Bakhtin: o signo é, por natureza, vivo e móvel, plurivalente; a classe dominante tem interesse em torná-lo monovalente (BAKHTIN, 1981, p.15).

De fato, o que vemos é que um setor da nobreza tenta exercer um controle sobre essa palavra-chave do circuito trovadoresco. Busca-se transformar essa "armadura elástica", no interior da qual os representantes de todos os segmentos sociais se comprimem, em uma "armadura de ferro", onde cabe apenas a nobreza. O gesso, antes material tão manuseável e flexível, se endurece para se tornar um único molde para o perfil aristocrático, formatando na imagem esculpida do trovador o correspondente cortesão do bellatore aristocrata. É assim que a fidalguia tradicional tenta pressionar a linguagem para imobilizar na palavra "trovador" o sentido que lhe convém. Naquele tempo, era mais rara a oportunidade de aprisionar a palavra em um dicionário, já que foi somente com a Renascença que, graças à invenção da imprensa, os 
${ }^{2} \mathrm{CV}$ será utilizada aqui como abreviatura de Cancioneiro da Vaticana (um dos três grandes cancioneiros onde se acha registrada a poesia dos trovadores galegoportugueses dos séculos XIII e XIV). grandes dicionários começaram a se multiplicar. Mesmo assim, a escrita não deixa de vir em socorro dos segmentos hegemônicos que a controlam. Vemos isto nos cancioneiros ibéricos compilados nos séculos XIII e XIV, por iniciativa régia ou aristocrática. Ali, sempre que se quer referir a um poeta-fidalgo, em qualquer comentário acrescentado a uma cantiga, ajunta-se-lhẹ a denominação "trovador". Ou então se remete a sua condição de "cavaleiro", outra palavra que também é uma armadura elástica mas que aqui assume a sua dimensão mais comprimida. Até quando depreciados, os nobres carregam a sua distinção. "Esta cantiga foi feita a um cavaleiro que lhe apoinham que era puto", diz a rubrica de uma cantiga de autoria de Estevão da Guarda no tempo de D. Dinis (CV 909)².

Mesmo aos trovadores-fidalgos notórios por trovarem mal - como certo Sueiro Eanes, que foi tão alvejado por seus colegas do trovadorismo galego-português (CV's 1117, 1170, 1179, 1184) —, é-lhes conferido o qualificativo de "trovador", contrariando aquela tese dos jograis-compositores segundo a qual o talento é que é verdadeira medida que se adapta à armadura trovadoresca. Posto isto, nada impede que estes últimos, diante de um trovador-fidalgo de talento inferior, emprestem à designação uma entonação pejorativa:

\footnotetext{
Sueir'Eanes, este trobador,

foi por jantar a cas dun infançon,

e jantou mal; mais el vingou-s' enton, que ar ajan os outros d'el pavor; e non quis el a vendita tardar: e, tanto que se partiu do jantar, trobou-Ihimal, nunca vistes peior.
}

(Pero da Ponte, CV 1179)

Nesse escárnio, o jogral galego não perde a oportunidade de alvejar simultaneamente o mau trovador e o infanção miserável, ambos nobres, sendo o jantar de um da mesma qualidade que a cantoria do outro. "Trovador" é, aqui, 
uma palavra manejada com explícita ironia, beirando o sarcasmo mais direto, e deixa no ar que a qualidade do trovar não está diretamente ligada à "nobreza do sangue", como o teriam desejado os fidalgos da corte.

Há um discurso oculto nas cantigas que depreciam os trovadores-fidalgos sem talento, venha da parte de um nobre ou de um jogral. Trata-se do discurso interno que conduz da "depreciação do trovador sem talento" à "depreciação do cavaleiro sem valor". E que, quando apropriado pelos setores não-aristocratas, questiona o status quoinsinuando a consideração de uma "nobreza do espírito". Note-se, desde já, que a crítica ao fidalgo sem talento comporta nuanças muito sutis, conforme quem a enuncia. É diferente insinuar que "só a nobreza não basta" ou que "não há nobreza de berço, mas somente de espírito".

A primeira perspectiva reafirma a valorização da origem aristocrática, mas a discrimina também por dentro, sendo o ponto de vista de uma elite que se pretende entrincheirar no coração da nobreza mais ampla (são os bemnascidos, mas hábeis, talentosos e bons cavaleiros, admitindo também os que fecham o círculo com um último requisito que é a fartura material). A segunda perspectiva é que é, consciente ou não, a dos cavaleiros vilãos e jograis que pretendem projetar-se, por exemplo, na corte. Criticam muito sutilmente o critério da nobreza pelo sangue, como se o quisessem substituir por um novo, o do valor e talento pessoal. A idéia, somente enunciada nas entrelinhas, conta com o reforço da poesia antinobiliárquica dos goliardos daquele tempo, tal como expressa a seguinte frase extraída de uma canção goliarda do século XII: "O nobre é aquele que a virtude enobreceu / O degenerado é aquele que virtude alguma enriqueceu" (LE GOFF, 1988, p.38).

Mas isto se dá em um grupo reduzido, já que a grande massa se mostra aqui vítima de uma difusão da ideologia dominante e se conforma dentro do ordenamento que lhe foi imposto, como "natural", desde o nascimento. Deve-se considerar, ainda, que a idéia de uma "nobreza do talento" insere-se também em um circuito mais amplo, que transcende as próprias infiltrações de interesses de classe. 
Por esse período inicia-se, precisamente, um longo processo de luta pela dignificação do artista. "Jean de Meung afirma que a nobreza do nascimento não é nada frente à nobreza do homem de letras". Tal como faz notar Umberto Eco (1989, p.153),

os poetas adquirem muito mais cedo a plena consciência de sua dignidade; se quanto às artes mecânicas são transmitidos apenas os nomes dos principais arquitetos, no que se refere à poesia toda obra tem seu autor definido, consciente, de qualquer modo, da originalidade de seus argumentos ou de seu estilo.

Quiçá, naquela crítica dos jograis talentosos contra os fidalgos inábeis, pode ser entrevisto ainda outro longo processo: a depreciação do trovador desajeitado com as palavras terá outra ponta naquela depreciação do cavaleiro desajeitado na sua totalidade de movimentos, que em um futuro não muito distante seria retratada na "triste figura" do Dom Quixote de La Mancha. Mas algo ainda nos separa desse outro tempo. Nas versões escritas dos cancioneiros ibéricos, os jograis de menor categoria, alguns de talento reconhecido, já não merecem uma similar qualificação à dispensada aos trovadores de berço nobre. Até na simples aposição de seus nomes no frontispício de uma cantiga costumam vir procedidos da designação de "jogral". Lourenço, jograr; Diego Pezelho, jograr... Ou então se discrimina por meio da incorporação de um apelido, pelo que já se reconhece que o poeta-cantor é um jogral... Pero da Ponte, Pedro Amigo, João Baveca... Somente aos nobres, o sobrenome. Além disso, distingue-se o trovador fidalgo fazendo o nome ser precedido da palavra "Dom". Somente como sarcasmo é que esta é aposta ao nome de um jogral. Dom Lourenço (CV's 1034, 1105); Dom Bernaldo (CV 663).

O signo "trovador", é claro, não permanece tão aprisionado, neste mundo de poucos dicionários, quanto desejaria a nobreza mais demarcadora. Temos um sinal disso na inexistência do aposto "jogral" ou "segrel" junto ao nome 
do cavaleiro vilão ducentista João Garcia de Guilhade, quando se cita a autoria de suas cantigas nos cancioneiros escritos. Indicativo, talvez, de que a palavra elástica se esticou até o talentoso cavaleiro vilão no vocabulário dos compiladores. Mas volta-se à refrega quando vamos aos textos das cantigas aristocráticas contra Guilhade, onde a interdição reaparece, negando-lhe o status de trovador tão galhardamente reivindicado pelo hábil poeta-cantor. Idas e vindas ...

As discriminações de status no interior da palavra "trovador" não aparecem somente no ambiente trovadoresco galego-português. Na Minnesang, o manuscrito de canções Heidelbergordena da seguinte maneira a sua lista de cantores: primeiro o imperador; depois os príncipes, condes, barões, ministerialese cavaleiros; depois a aristocracia urbana, o clero, os letrados, os comerciantes e burgueses (SCHULTE, 1895, p.185/251). Aqui, a contração do signo é enfatizada por um ordenamento que é imposto à lista de trovadores. Como se percebe, cada círculo aristocrata e cada trovadorismo de corte elaboram as suas próprias estratégias de demarcação e de compartimentação do signo verbal.

Os constrangimentos impostos ao signo pela passagem da oralidade à escrita inscrevem-se, dessa forma, na subterrânea batalha pelo poder de nomear onde alguns tentam restringir pela palavra o que se quer restringido socialmente. Para o caso das versões escritas do cancioneiro, "é necessário recordar vigorosamente que não existe nenhum texto fora do suporte que o dá a ler, que não há compreensão de um escrito, qualquer que ele seja, que não dependa das formas através das quais ele chega ao seu leitor" (CHARTIER, 1989, p.127). Assim, os cancioneiros escritos, novo suporte para aquela poesia que circulava no território da oralidade, acrescentam certas estratégias demarcatórias àquelas outras que antes havia ${ }^{3}$.

O destino de uma palavra é o destino da sociedade que a pronuncia. A medida que a sociedade feudal foi se desestamentizando, a palavra "trovador" foi perdendo também seus compartimentos secretos, seus íntimos aposentos reservados para cada inquilino social. Foi perdendo as divisórias internas em favor de um espaço único, tal como
${ }^{3} \mathrm{O}$ próprio silêncio imposto a uma parte da produção trovadoresca deve ser considerado, por seu turno, como uma estratégia demarcatória. Aqui se enquadra, para citar novamente um exemplo do trovadorismo ibérico, a ausência das "cantigas de vilão" nos cancioneiros escritos. Elas são mencionadas no capítulo VIII do tratado trecentista "A Arte do Trovar" como um gênero bem definido. E, no entanto, não foram incluídas em nenhum dos cancioneiros produzidos nos meios aristocráticos e palacianos. Parece haver uma referência a elas na CV 965 de Martim Soares, onde se deprecia um cavaleiro nobre de cantares populares. 
teriam desejado aqueles jograis que sutilmente questionavam o status quoaristocrático. Atravessa o Renascimento já com um novo significado que predomina sobre os demais. Para os enciclopedistas renascentistas, como o Ângelo Colloci, a quem se deve a preservação do Cancioneiro da Biblioteca Nacional, "trovador" é já qualquer músico-poeta que freqüentava o ambiente das cortes. Mas, como são colecionadores imbuídos da nova mentalidade enciclopedista, colecionam também sentidos e buscam aprisionar significados. Por isso conservam os espaços internos da palavra medieval com a reprodução inalterada de seus documentos, ou, ao menos, permitem que aquelas informações nos cheguem nas suas notas marginais e rubricas explicativas.

Hoje em dia, vivemos em uma sociedade de classes em que, pelo menos em tese, a passagem de um segmento social a outro é menos interdita (no caso, regida principalmente pelo poder econômico). Sobretudo, trata-se de uma sociedade multifuncionalizada, onde a profissão ou a ocupação é um elemento fixador da identidade do indivíduo. Não é a-toa que, na sociedade contemporânea, sempre que se pronuncia a palavra "trovador" o primeiro sentido a que se remete é o do "poeta-cantor que freqüentava os castelos medievais (independente de sua origem social)". Ou seja, a palavra acompanhou a desestamentização da sociedade. Tanto que, enquanto escrevo este artigo, preciso acrescentar o adjetivo "fidalgo" à palavra "trovador", se quero deixar claro para o leitor que se trata de um trovador da alta nobreza. Caso contrário, o sentido que escapa é aquele mais geral dos poetascantores (função, ocupação) que se apresentavam nas cortes medievais (meio social).

Também esse sentido já existia, destarte, na sociedade feudal. Era invocado, a bem dizer, quando se pretendia fixar uma distinção entre os poetas-cantores que atuavam no circuito das cortes e aqueles que atuavam fora deste circuito - por exemplo, os que atuavam nas tabernas, universidades e praças públicas. O signo verbal é, portanto, um instrumento para fixar a identidade por oposição ao "outro". Ou para construir a imagem da corte como "centro de cultura", por oposição ao "outro" periférico. Dessa forma, 
a penúltima fronteira da designação "trovador" - antes de ela se diluir naquele sentido mais amplo que se fecha em torno de todos os poetas-cantores medievais - é o próprio círculo cortesão. Trovadores seriam todos aqueles que participam desse ambiente comum, independentemente de suas origens sociais. A sociedade inteira, com todas as suas nuanças, prefigura-se nesses seus representantes e porta-vozes que adentram os limites das cortes régias e senhoriais.

Entre os trovadores que freqüentavam o circuito cortesão, iremos encontrar então todos os tipos e representações sociais - do poderoso monarca (Afonso X, D. Dinis, Ricardo Coração-de-Leão, Afonso II de Aragão) ao mais humilde jogral, às vezes anônimo e outras vezes notório (Cercamon, Guiraut Riquier). No interior do espectro assim formado, toda a sociedade tem sua voz - condes como Guilherme de Poitiers e a Condessa de Dia; nobres na fronteira estamental como o minnesänger Walther von Vogelweide; clérigos marginais como Airas Nunes de Santiago; e toda uma diversidade de situações possíveis.

É por ser este caleidoscópio social que o ambiente trovadoresco se torna ao mesmo tempo um laboratório de experiências humanas e um palco onde toda a sociedade se espelha: um dos ambientes trovadorescos privilegiados para percebermos como essas disputas que já se davam no próprio interior da palavra "trovador" era o ambiente lírico dos trovadores galego-portugueses, nas cortes ibéricas do século XIII. No próximo e último bloco, veremos como essa disputa se dá nesse ambiente lírico, mostrando que o mesmo jogo de tensões que se estabelece no interior da palavra se projeta também no ambiente social dos trovadores, e vice-versa.

Um mergulho na própria poesia trovadoresca nos permitirá examinar a partir daqui o jogo de tensões sociais que se expressava através do ambiente dos trovadores medievais e que ficou registrado nos grandes cancioneiros da época. Particularmente nas cortes régias de Portugal e de Castela - esses dois pólos do trovadorismo galego- 
${ }^{4}$ A poesia desse circuito trovadoresco está registrada em alguns cancioneiros. $\mathrm{O}$ Cancioneiro da Ajuda teria sido compilado na corte de Afonso X de Castela, na segunda metade do século XIII. Na primeira metade do século XIV teria sido compilado um Livro de Cantigas do Conde Dom Pedro que, embora desaparecendo posteriormente, teria dado origem ao Cancioneiro da Vaticana e ao Cancioneiro da Biblioteca Nacional, dois cancioneiros compilados na Itália já no século XVI. Esses dois cancioneiros, somados ao Cancioneiro da Ajuda, constituem grandes coletâneas da poesia trovadoresca ibérica que, à sua época, circulava nas cortes régias de Portugal e Castela. Os manuscritos encontram-se atualmente nas bibliotecas que lhes emprestam seus nomes: Biblioteca da Ajuda (CA), Biblioteca da Vaticana (CV), Biblioteca Nacional (CBN). Os três cancioneiros conhecidos encontram-se atualmente impressos, contando com ediçōes importantes das quais elegemos a de Carolina Michaëlis para o Cancioneiro de Ajuda (1904), a de Teófilo Braga para o Cancioneiro da Vaticana (1878), e a de Elza Pacheco Machado para o Cancioneiro da Biblioteca Nacional (1949-1964) português dos séculos XIII e XIV — , o ambiente trovadoresco apresentava-se explicitamente como uma grande arena aberta à expressão das tensões sociais e individuais ${ }^{4}$. Mesmo o jogral popular da mais humilde condição social era livre para rivalizar e afrontar poeticamente os trovadores-fidalgos. A poesia, como nunca, era empunhada por pequenos e grandes como se fosse uma espada; os combates se davam no ambiente trovadoresco do Paço e ali mesmo se resolviam, sob o olhar sábio de um rei que se colocava como protetor e promotor da cultura, como mediador da diversidade social, como monarca multirrepresentativo capaz de penetrar em todas as ordens e circuitos culturais - do sagrado ao profano, do popular ao aristocrático, do rural ao urbano.

Eram comuns, nessas "arenas trovadorescas" ibéricas, cantigas de escárnio e de maldizer, que podiam até ter como alvo o rei, o que demonstra a relativa liberalidade dos paços trovadorescos. Este é o caso da cantiga abaixo, movida pelo fidalgo Gil Peres Conde contra o rei Afonso X de Castela, que também era, aliás, um dos mais hábeis trovadores:

Os vossos meus maravedis, senhor, que eu non ouvi, que servi melhor ou tan ben come outr'a que os dan, ei-os d'aver enquant'eu vivo for, ou a mia mort', ou quando mi os daran?

A vossa mia soldada, senhor Rei, que eu servi e serv'e servirei, com'outro quen quer a que dan ben, ei-a d'aver enquant' a viver ei, ou a mia mort', ou que mi faran en?

Os vossos meus dinheiros, senhor, non pud'eu aver, pero servidos son, Come outros, que os an de servir, ei-os d'aver mentr'eu viver, ou ponmi-os a mia mort' o a que os vou pedir? 
Ca passou temp' e trastempados son, ouve an'e dia e quero-m' en partir.

(Gil Pérez Conde, CBN 1523)

A cantiga acima é uma das mais engenhosas do cancioneiro escarninho. O fidalgo português Gil Peres Conde, que servira o rei de Castela na guerra da Andaluzia, queixa-se das dificuldades em obter as soldadas correspondentes aos serviços prestados. Em outras palavras, acusa o rei de "mau pagador" - o que, nesse caso, significa acusá-lo de mau cumpridor das obrigações geradas pelos vínculos de vassalidade. São engenhosos e bem-humorados os artifícios poéticos encontrados pelo nobre, que joga com o duplo uso de pronomes possessivos, "vossos" e "meus", referindo-se aos maravedis que estavam de posse do rei mas que, por direito, deveriam ser seus. "Os vossos meus maravedis", "A vossa mia soldada", "Os vossos meus dinheiros" - o trovador pergunta se os receberá durante a vida ou somente à hora da morte.

O "duplo possessivo" aqui empregado, com originalidade absoluta, é um exemplo notável daquela capacidade de trazer o confronto para dentro de uma única expressão. Tornada ambígua, e provavelmente acompanhada de uma entonação irônica no plano da oralidade, a palavra poética expressa aqui o entrechoque de dois interesses. O do monarca, que naqueles tempos perturbados e de dificuldades econômicas acabava por vezes atrasando as soldadas, e o do vassalo, exigindo o pagamento imediato, por considerá-lo uma obrigação suserana.

Brigam os dois possessivos, "meus" e "vossos", disputando o espaço com que se colam ao substantivo, que para o fidalgo representa um "direito", mas que, para o monarca, se insinua como uma "obrigação". O entrechoque poético e inusitado entre os dois possessivos é, dessa forma, o entrechoque entre um direito e uma obrigação, entre o vassalo e o suserano, entre uma 
necessidade e outra. Quantas disputas secretas não se insinuam nesse torneio imaginário que se celebra no interior de uma única palavra poética! Além de uma queixa contra a dívida não paga, deve-se buscar nessa cantiga o texto sob o texto: ela invoca indiretamente o próprio conjunto de instituições feudo-vassálicas, e coloca o monarca na posição de um senhor que se beneficiou dos serviços do vassalo mas que se recusa a cumprir suas obrigações de suserano. Competem, dessa maneira, o modelo do "bom vassalo" e o contramodelo do "mau suserano".

Vejamos agora que, por trás desses combates, se dá outro. É o próprio "embate centralizador" que produz sua centelha desde o entrechoque dessas muitas espadas. O "rei centralizador" é muitas vezes um "mau suserano". Nos tempos mais difíceis, a sua necessidade o leva a unilateralizar uma obrigação que, do ponto de vista estritamente "feudal", deveria carregar a inseparável sombra da reciprocidade. Vista pelo circuito dos ideais vassálico-cavaleirescos, a expressão "senhor" repetida em cada uma das três estrofes (por exemplo, "senhor rei") assume, dessa forma, um sentido a mais, além do vocativo respeitoso, remetendo às obrigações de senhor (suserano) que o rei teria descumprido.

Por tudo se vê que - dentro de um contexto em que se vem dando, no plano político, um embate entre o projeto régio centralizador e uma "contratendência feudalizante" de parte da nobreza do reino - a cantiga aqui discutida compõe com outras cantigas análogas do mesmo trovador uma defesa dos direitos senhoriais. Tratase de um exemplo particularmente interessante de como as tensões de ordem política podiam se projetar nos ambientes trovadorescos.

Da mesma forma que ocorria no caso das cantigas de escárnio, os conflitos de toda ordem também se projetavam em outro conhecido gênero poético do cancioneiro satírico da medievalidade ibérica. Veremos a seguir que as tençõespunham freqüentemente em confronto poetascantores pertencentes a distintas categorias sociais. Esse gênero era já conhecido nas cortes provençais e na 
minnesang. A forma era constituída de uma alternância de estrofes, em que um trovador respondia ao outro à maneira de um desafio. O dado fundamental é que, nas cortes feudais européias, mesmo que esses disputatios líricos envolvessem trovadores aristocratas e menestréis de categoria social inferior, o tema central da tensó jamais envolvia uma questão de fundo social. Discutia-se em torno da "amatória" (questões relativas ao amor cortês), ou então sobre "estilística".

Ao contrário, na "tenção" galego-portuguesa", era muito comum haver dois tipos sociais antagônicos, o jogral assoldadado e o trovador fidalgo, a duelar liricamente com conotações sociais:

- Juião, quero tigo fazer, se tu quiseres, ua entençon: e querrei-te, na primeira razon, ua punhada mui grande poer eno rostro, e chamar-te rapaz mui mao; e creo que assi faz boa entençon quena quer fazer.

- Meen Rodriguez, mui sen meu prazer a farei vosc', assi Deus me perdon: ca vos averei de chamar cochon, pois que eu a punhada receber; des i trobar-vos-ei mui mal assaz, e atal entençon, se a vós praz, a farei vosco mui sen meu prazer.

— Juião, pois tigo começar fui, direi-t' ora o que farei: ua punhada grande te darei, des i querrei-te muitos couces dar na garganta, por te ferir peor, que nunca vilão aja sabor doutra tençon comego começar. 
- Meen Rodriguez, querrei-m' en parar,

se Deus me valha, como vos direi:

coteife nojoso vos chamarei,

pois que eu a punhada recadar;

des i direi, pois so os couces for:

'Le[i]xade-m' ora, por Nostro Senhor',

ca assi se sol meu padr' a en parar.

— Juião, pois que t' eu [for] filhar

pelos cabelos e que t' arrastrar,

que dos couces te pès eu creerei.

- Meen Rodríguez, se m' eu estropiar, ou se me fano, ou se m' entortar, ai, trobador, já vos non travarei.

(Meen Rodríguez Tenoiro e Juião Bolseiro; CBN 403)

A estrutura de tenção é típica: através dela, os dois trovadores se ocupam de depreciar um ao outro em estrofes alternadas. Nesse sentido, ao invés de a tenção girar em torno de uma questão genérica, o que se vê é uma sucessão de ataques pessoais que oculta um verdadeiro conflito de categorias sociais. Mem Rodrigues Tenório pertencia a uma das mais ilustres famílias galegas e à melhor nobreza da Península. Quanto a Juião Bolseiro, este era um jogral que também atuava com sua margem de atrevimento, embora muito menos que Lourenço, mas que aqui aparece curiosamente comedido diante das ameaças de Tenório.

Estamos aqui diante de uma tenção proposta em termos de rara agressividade. Quase que toma a forma lírica de uma "briga de rua", não fosse Juião Bolseiro, perante a total agressividade de Tenório, replicar com certo comedimento. Enquanto o fidalgo principia por dizer que sua primeira razão é um murro no rosto (v. 4/ 5), Juião, no máximo, lhe responde com alguns insultos ("cochon", por exemplo, é uma expressão pejorativa normalmente dirigida por aristocratas a vilãos). Talvez 
porque, sem querer partir para o que poderia descambar para um confronto físico, ou então extrapolar a tensão trovadoresca apresentada liricamente, o jogral tentasse responder a isso com mais dignidade e astúcia poética. Apropria-se então das próprias palavras injuriosas que os nobres costumavam dirigir aos vilãos e procura voltá-las contra o fidalgo agressor, talvez a insinuar algo sobre quem se comporte como um verdadeiro "cochão" (v. 10), ou ainda um "coteife nojoso" (v. 24).

Tenório, por sua vez, continua ao longo de todas as estrofes a desfechar suas ameaças físicas, como, por exemplo, na terceira estrofe, onde afirma que "irá lhe dar muitos coices na garganta, para feri-lo tanto que desde então nenhum vilão mais se atreverá a entençoar com ele" (v. 18/21). É a demarcação social levada a seu extremo, com rara agressividade em uma tençãotrovadoresca nesse meio em que tudo parece se resolver liricamente. Significativo nos parece o contraste entre a agressividade do nobre e o comedimento do jogral, pois nos mostra que os limites de um não são iguais aos limites do outro. Em todo o caso, o exemplo acima fica apenas como um registro extremo dessa oposição entre dois representantes de segmentos sociais que se antagonizam através da sátira trovadoresca. Oposição que, na maior parte das vezes, se concentra na disputa estritamente lírica, na desmoralização pelo riso, no rebaixamento pela palavra. O "combate corpo a corpo" assume em quase todos esses casos a forma de um "combate verso a verso", e se volta fundamentalmente para o campo da "violência simbólica".

Embora a tenção acima discutida tenha trazido à tona o limite entre dois grupos sociais bem definidos, por outro lado eram igualmente comuns as tenções nas quais rivalizavam sem maiores entraves um poeta-cantor fidalgo e um jogral de categoria menor, mostrando que por vezes na "arena trovadoresca" se mostravam como que suspensas as regras que, fora, regiam as relações sociais. Assim principia uma tenção (CV 1010) entre o célebre jogral Lourenço, de nível social equivalente ao "peão", e o fidalgo João Peres de Aboin: 
— Lourenço, soias tu guarecer

como podias, per teu citolon,

ou ben ou mal, non ti digu' eu de non,

e vejo-te de trobar trameter;

e quero-t' eu desto desenganar:

ben tanto sabes tu que é trobar

ben quanto sab' o asno de leer

À insinuação de que "sabe tanto de trovar quanto um asno de ler", Lourenço replica assumindo a posição de um "bellatorlírico". Lembra a seu contendor que já venceu, em tenção como aquela, vários outros trovadores-fidalgos, que partiram da mesma insinuação. Agora, pretende derrubar o famoso mordomo de Dom Afonso III:

- Joan d' Avoin, já me cometer

veeron muitos por esta razon

que mi dizian, se Deus mi perdon,

que non sabia n trobar entender;

e veeron poren comigu' entençar,

e figi-os eu vençudos ficar,

e cuido-vos deste preito vencer

A tenção assume aqui toda a sua forma de duelo, de combate lírico onde um trovador se assume como oponente do outro. O verso seguinte é tipicamente demarcatório. Aboin reafirma seu propósito de "desenganar" ao jogral Lourenço quanto a seu propósito de seguir sendo trovador:

- Lourenço, serias mui sabedor,

se me vencesses de trobar nen d' al,

ca ben sei eu quen troba ben ou mal,

que non sabe mais nen um trobador;

e por aquesto te desenganei;

e vês, Lourenço, onde cho direi:

quita-te sempre do que teu non for. 
Demarcação por uma dupla via. Por um lado, enaltece a si mesmo e à sua condição de trovador. Só ele, como trovador (isto é, trovador-fidalgo), seria ali capaz de prejulgar quem trova bem ou quem trova mal. E, mais, de outro lado a interdição explícita: o espaço composicional-trovadoresco é naturalmente estranho a um jogral de condição inferior ("quita-te sempre do que teu non for"). Depois do quê, Lourenço encerra sua participação afirmando que, de forma nenhuma, abandonará o trovar. Primeiro, porque tem plena consciência de seus méritos. Também porque encontra na sua atividade uma grande fonte de prazer e satisfação:
- Joan d' Avoin, por Nostro Senhor, por que leixarei eu trobar atal que mui ben faç' e que muito mi val?
Des i ar gradece-mi o mia senhor, por que o faç'; e, pois eu tod' est' ei, o trobar nunca [o] leixarei, poi-lo ben faç' e ei [i] gran sabor

"Tirar do trovar um grande sabor" - é um derradeiro imiscuir-se na esfera de atitudes da nobreza para com a trova. O jogral declara que, da mesma forma que muitos fidalgos trovam por um prazer do espírito, o trovar é, para ele, muito mais do que uma profissão. Rejeição, portanto, daquela habitual demarcação dos trovadores-fidalgos segundo a qual a poesia deve ser para o jogral apenas uma profissão, um meio de subsistência, se possível na função de mero acompanhante dos trovadores nobres. O ambiente trovadoresco, enfim, mostrava-se aqui capaz de constituir a mesma arena que, tal como vimos no início deste artigo, se dava no interior da própria palavra "trovador". 


\section{Referências}

BAKHTIN, Mikhail (Volochínov, V. N.). Marxismo e filosofia da linguagem. São Paulo: Hucitec, 1981.

BALANDIER, Georges. O poder em cena. Brasília: Editora Universidade de Brasília, 1980.

BOURDIEU, P. O poder simbólico. Lisboa: Difel, 1989.

BRAGA, Teófilo (Org.). Cancioneiro portuguez da Vaticana. [S. 1.]: [s. n.], 1878.

CARMINA BURANA. Canções de Beuern. São Paulo: Ars Poética, 1984.

CHARTIER, Roger. A história cultural: entre práticas e representações. Lisboa: Difel, 1990.

ECO, Umberto. Arte e beleza na estética medieval. Rio de Janeiro: Globo, 1989.

HAROCHE, C., HENRY, P. e PÊCHEUX, M. La sémantique et la coupure saussurienne: langue, langage, discours. Langages 24 , dez. 1971.

LE GOFF, Jacques. Os intelectuais na Idade Média. São Paulo: Brasiliense, 1988.

MACHADO, Elza Paxeco; MACHADO, José Pedro (Orgs.). Cancioneiro da Biblioteca Nacional. Lisboa: Ocidente, 19491964.

SCHULTE, A. Standesverhaeltnisse der Minnesinger. In:

Zeitschrift für deutsches Altertum und deutsche Literatur, 1895 , p.185/251.

SPITZER, Leo. Perspectivism in Don Quixote. In: SPITZER, Leo. Linguistics and literary history, New York: Russel and Russel, 1948.

VASCONCELOS, Carolina Michaëlis de (Org.). Cancioneiro da Ajuda. Halle: [s. 1.], 1904. 2.v. 